\title{
Cultura Cultura
}

Revistade historia e Teria das ldeais $\quad$ Revista de História e Teoria das Ideias

Vol. $26 \mid 2009$

0 Tempo das Revistas

\section{Pensamento e actualidade}

As revistas no século XX

Thought and actuality. The magazines of the $20^{\text {th }}$ century

\section{Luís Andrade}

\section{OpenEdition}

Journals

Edição electrónica

URL: http://journals.openedition.org/cultura/370

DOI: $10.4000 /$ cultura.370

ISSN: 2183-2021

Editora

Centro de História da Cultura

Edição impressa

Data de publição: 1 Junho 2009

Paginação: 19-49

ISSN: 0870-4546

Refêrencia eletrónica

Luís Andrade, «Pensamento e actualidade », Cultura [Online], Vol. 26 | 2009, posto online no dia 16 setembro 2013, consultado a 21 abril 2019. URL : http://journals.openedition.org/cultura/370 ; DOI : 10.4000/cultura.370 


\title{
Pensamento e actualidade. As revistas no século XX
}

\author{
Luís Andrade*
}

\section{O século das revistas}

As revistas desempenharam, entre finais do século XIX e o derradeiro quartel do século XX, um papel primordial na vida contemporânea, pois os vigorosos movimentos de pensamento, de sensibilidade e de acção característicos da época singraram, por regra, através deste género de periódicos.

As páginas das revistas deram, então, a conhecer manifestos intransigentes, orientações doutrinárias veementes, gramáticas artísticas e de gosto ousadas, focos de interesses colectivos centrípetos, correntes de opinião marcantes, firmamentos simbólicos inéditos e estilos de vida irreverentes.

A simples consulta de alguns exemplares avulsos dos muitos títulos salientes permite captar o teor dos géneros e dos registos que fizeram com que os seus leitores se tenham visto conduzidos, mesmo nos círculos conservadores, pelo enlevo da consciência e da sensibilidade tidas por contemporâneas, imputável, invariavelmente, à novidade incontestável dos tempos.

Ao mesmo tempo, as revistas rasgaram as janelas que permitiram aos homens e às mulheres comuns franquear, de forma massiva, as circunscrições insulares das culturas tradicionais e aceder, pela imagem e pela palavra, a realidades, efectivas ou imaginárias, surpreendentes.

Em Portugal, como nos outros países desenvolvidos, a actividade dos homens do pensamento, das letras e das artes, bem como a da generalidade dos publicistas, viu-se absorvida pela redacção nos hebdomadários, quinzenários e mensários que fizeram o pulsar, por vezes muito vigoroso, da realidade cultural nacional.

Os autores de relevo, incluindo os mais reputados, não só publicaram regularmente nas revistas originadas nas redes de afinidades pessoais, intelectuais, profissionais e programáticas em que estavam incluídos, como também se destacaram, com muita

\footnotetext{
Seminário Livre de História das ideias, Centro de História da Cultura da Faculdade de Ciências Sociais e Humanas da Universidade Nova de Lisboa.
} 
frequência, como fundadores, directores ou redactores proeminentes de um ou mais títulos destes periódicos.

A publicação regular em revistas por parte daqueles que mais sobressaíram em cada uma das áreas da vida cultural portuguesa contrastou mesmo com a escassa produção de estudos com teor original.

Feita excepção às obras de narrativa romanesca e às escassas monografias destinadas a satisfazer finalidades específicas, verifica-se com facilidade que parte muito significativa dos livros publicados pelos autores mais estimados - para muitos, a quase totalidade das suas obras - consistiu na reunião de textos doutrinários, ensaísticos, literários ou académicos anteriormente dados a conhecer no corpo das publicações periódicas em que haviam colaborado, muitas vezes, durante anos a fio'.

Quem tenha detido a sua atenção no século considerado não terá dificuldade em ilustrar com exemplos próprios, de âmbito geral ou no domínio específico de interesses particulares, o lugar central das revistas na vida da época. As correntes de doutrina política, os movimentos literários, as tendências e as escolas de pensamento - filosófico, pedagógico, filológico, histórico, sociológico, nos seus vários matizes - deram a conhecer as suas teses, os seus programas e as suas referências através dos artigos que as figuras que lhes presidiram publicaram em periódicos de ideias e cultura.

Em todos os domínios da vida cultural, as revistas passaram a constituir fontes não só primordiais como, a seu modo, completas.

Enquanto os leitores das revistas mais representativas do século XX acedem, com facilidade, ao panorama è dinâmica dos movimentos de ideias e da vida cultural portuguesa, de tal modo estes periódicos constituem os repositórios fiéis das orientações e dos registos do intenso fluir cultural da época, todos aqueles que, pelo contrário, descurem estas fontes primordiais não ultrapassarão o limiar da apreciação fragmentária, vulnerável ao anacronismo conceptual e exposta à credulidade envolvente das memórias com que cada movimento de ideias compôs a imagem da identidade própria e as representações daqueles com que, de forma mais ou menos veemente, se confrontou.

\footnotetext{
A propósito do movimento editorial nas três primeiras décadas do século XX, Rui Ramos sublinhou-o: "o mundo dos livros era apenas um anexo do mundo da imprensa, que era quem dava os pés ao império dos escritores" e "muitos dos livros publicados nesta época são simples colecções de textos com que os autores, ocasional ou regularmente, contribuíram para jornais e outras publicações periódicas (...) a ânsia de publicar imediatamente era enorme" (Rui Ramos, História de Portugal, vol. VI, Lisboa, Editorial Estampa, 2001, pp. 54 e 471).
} 
Em suma, as revistas urdiram, durante décadas sucessivas, a vida e o ambiente cultural. Exibiram a cultura portuguesa, na complexidade das suas vozes, dos seus sentidos e das suas dinâmicas, quer ao reunirem a produção reflexiva, literária e mesmo artística das figuras públicas, quer ao promoverem e espelharem a mudança das mentalidades e dos usos.

Os títulos consagrados, a par de outros caídos na penumbra, constituíram o fundamento e o alento de uma era cuja vivacidade ideológica, cultural e cívica deixou sobressair com toda a nitidez o recorte fogoso que a caracterizou, quando confrontada com a atonia ideológica, a debilidade doutrinária, a rasura de sentimentos e a rarefacção cívica das décadas finais do século XX, anunciadas e expostas, aliás, igualmente em páginas de revistas, precisamente naquelas em que o ciclo assinado encontrou o epílogo.

O significado de que as revistas se revestiram, ao longo do período genericamente referido, ganhou uma expressão tão intensa que aconselha a considerar esta modalidade de imprensa, nos traços que determinam a sua peculiaridade, como objecto de investigação e de reflexão autónomo.

Como é sabido, as condições particulares de produção e de circulação das ideias e das representações culturais não constituem um simples dado circunstancial,com significado e alcance instrumentais. No caso das revistas, como de muitas outras modalidades de comunicação colectiva, oral ou escrita, a discursividade e os termos da sua expressão pública caminharam a par, estabelecendo entre si vínculos indeléveis.

Assim sendo, só a consideração das características específicas das revistas como modalidade de imprensa permite revelar o quadro editorial em que a cultura escrita da época considerada se desenvolveu. Esta observação possibilita, desde logo, atender aos géneros jornalísticos, reflexivos e literários mais cultivados - editorial, artigo, crónica, texto de divulgação, poema, conto e novela, entre outros - e recordar as regras a que obedeciam, ou seja, perspectivar a compreensão dos universos de enunciação disponíveis a partir da apreciação dos protocolos relativamente rígidos. Permite, de seguida, consorciar a actividade cultural com as condições da produção editorial, através da apreciação do papel reservado aos diferentes tipos de objectos impressos. Faculta, por fim, a apreensão de disposições gerais respeitantes às modalidades de relacionamento entre publicações e públicos.

\section{A revista como modalidade editorial}

As revistas distinguiram-se, antes de mais, pela sua diversidade. Variaram na motivação que Ihes deu origem, comercial, cívica, ideológica, associativa, entre muitas outras; 
no teor, pois todas as grandes áreas temáticas e da vida social conheceram títulos específicos; na dimensão, do formato de bolso ao volume solene e decorativo; no público, da dona de casa aos cultores do esperanto; na finalidade, recreativa, utilitária, prosélita; na periodicidade, semanal, quinzenal, mensal, trimestral, anual ou, mesmo simplesmente, circunstancial ou irregular.

Sendo a história das revistas parte da história contemporânea, estes periódicos acompanharam as vicissitudes dos tempos, nomeadamente no que respeitou à evolução da parcela da população letrada, aos condicionalismos que afectaram o exercício da liberdade de expressão, aos preços do papel e dos outros aspectos da produção, aos movimentos sociais e à mudança nos hábitos culturais.

Num plano mais restrito, a história das revistas foi inseparável das transformações que marcaram o evoluir da imprensa e da comunicação social do século XX. As revistas beneficiaram, amplamente e ao longo de décadas, dos progressos no registo e na impressão de imagens, ao fazerem valer a ilustração e a fotografia, nomeadamente em reproduções em policromia ${ }^{2}$, nas suas páginas, ao mesmo tempo que viram a relevância relativa de que desfrutaram ao longo de decénios sucessivos ficar diminuída com a preponderância muito acentuada dos meios audiovisuais, no último quartel do século XX, em particular da televisão em emissão a cores e em registo de vídeo, entre os meios de comunicação social.

Porém, a compreensão do carácter destas publicações periódicas, ao longo do ciclo já balizado, não fica comprometida nem pela diversidade das suas expressões, nem pela sucessão de alterações radicais que a evolução da comunicação social conheceu, determinadas, na maioria dos casos, por saltos técnicos bruscos e revolucionários.

É, pelo contrário, possível não só identificar com rigor os traços distintivos das revistas, no quadro das publicações impressas e mesmo dos órgãos de comunicação social, considerados na sua generalidade, como também caracterizar com nitidez o papel ímpar e central que ocuparam, em virtude da natureza que Ihes foi própria, na história das ideias e da cultura contemporânea.

2 Sobre a evolução técnica da impressão, designadamente do apuro na reprodução massiva de imagens, da tricromia em impressão plana, por similigravura (1880), depois, heliogravura (1895) e, por fim, offset (1904), ao impulso inicial da impressão a cores em rotativa (meados da década de 1910), veja-se Daniel Renoult, “Les nouvelles possibilités techniques: le triomphe de la mécanique”, in Roger Chartier e HenriJean Martin (dir.), Histoire de l'édition française. Le livre concurrencé 1900-1950, Paris, Fayard/Cercle de la Librairie, 1991, pp. 28-50. 
O esclarecimento nítido destas duas dimensões beneficia se considerarmos a actividade editorial de revistas das décadas iniciais do século $\mathrm{XX}$, em que a Primeira República portuguesa se inclui, como referência paradigmática da afirmação e do cultivo deste tipo de publicações.

A tentativa de caracterizar as revistas como modalidade específica de imprensa, no quadro da grande diversidade de critérios editoriais que conferiram a cada uma destas publicações uma identidade própria, obriga, por um lado, à identificação de um conjunto de atributos específicos, alguns constantes e outros simplesmente correntes, e, por outro lado, ao confronto com outras modalidades editoriais, designadamente com os jornais, os livros e os boletins, de modo a distinguir, pela confrontação, as linhas de contorno e as tonalidades de cada um destes tipos de publicações.

A consulta singela de uma destas publicações periódicas deixa, por regra, transparecer, nos dizeres impressos no cabeçalho e na ficha técnica, bem como através de folhear ligeiro, quer a identificação própria através da especificação singular dos quesitos peculiares destes periódicos, quer outros atributos fundamentais, nomeadamente de natureza gráfica e física.

A observação imediata permite, só por si, concluir que as revistas se distinguem por ser publicações periódicas, com cadências de publicação predefinidas, mais ou menos compassadas, elaboradas por vários redactores ou colaboradores, compostas por peças editoriais de um ou mais géneros literários e jornalísticos, revestindo-se da forma de brochura com capa e contracapa. Embora se encontrem revistas comemorativas com número único - que assinalam, por regra, essa sua condição anómala - e se registem casos muito invulgares de edições que conheceram, voluntária ou involuntariamente, um só autor, e mesmo números editados com um só artigo, estas excepções relevam inteiramente do recurso a soluções circunstanciais, atípicas e mesmo insólitas, não constituindo qualquer versão particular da modalidade editorial, mas antes um seu simulacro episódico.

Aos atributos comuns apontados, é necessário acrescentar outras particularidades correntes, embora de observância menos estrita. Destaquemos quatro: o artigo como género usual, a orientação editorial desdobrada em conjuntos de peças variadas, a combinação entre texto e imagem, a focagem temática e a correspondente segmentação de destinatários.

$\mathrm{O}$ artigo constituiu o género jornalístico mais saliente nas revistas, pois directores, redactores e colaboradores utilizaram-no, de forma quase invariável, para apresentar programas, expor concepções, defender posições, explanar temas, desenvolver 
opiniões, tecer comentários e formular apontamentos. Com as excepções dos títulos literários, artísticos ou puramente recreativos, as revistas foram obra, em primeiro lugar, de articulistas, designação comum e apropriada para todos aqueles que discorreram, de forma mais ou menos habitual, nas suas páginas.

A plasticidade do artigo condiz, aliás, com a natureza facetada das revistas. Mesmo os periódicos que apresentaram maior rigidez programática não deixaram de ser, número após número, publicações caracterizadas pela adição de vozes, abordagens, interesses, temas, estilos e registos variegados, a tal ponto que cada edição pode ser encarada como um exercício singular na sucessão de compromissos entre a orientação geral e a diversidade das peças publicadas, balizados pela rejeição da uniformidade monótona e pela recusa da dispersão amorfa. Segundo critérios de latitude muito variável e de acordo com composições mais ou menos felizes, foi na declinação de questões, na pluralidade de autorias, no plissado de géneros e de registos que cada novo número insinuou e replicou a tensão essencial da realidade que presumia reflectir e recriar.

Neste domínio, a combinação entre texto e imagem desempenhou, a vários títulos, um papel central na afirmação das revistas, que frequentemente destacaram, em título ou em subtítulo ${ }^{3}$ a condição de publicações ilustradas: em primeiro lugar, pela divulgação de gravuras e de outras produções artísticas, fosse através da publicação de originais, pois foram muitos os artistas plásticos que colaboraram, a diferentes títulos, em revistas ${ }^{4}$, fosse pela reprodução de obras do património artístico nacional e internacional, num caso e no outro segundo técnicas de reprodução e de impres-

3 Dois exemplos muito conhecidos: a llustração Portuguesa, propriedade do jornal O Século, inicialmente dirigida por Carlos Malheiro Dias, que publicou 959 números, entre 1906 e 1930; e A Águia. Revista ilustrada de literatura e crítica, editada no Porto, em cinco séries, entre 1910 e 1932 . Noutros casos, a presença de ilustração, apesar de não surgir no título, era apresentada como argumento de peso. Foi o que se verificou com Contemporânea, cujo anúncio, que antecedeu, em Março de 1915, a publicação dos números espécimen, assim justificava a necessidade da nova revista de "arte, literatura, teatros, sport, modas \& elegâncias, sociedade": "a falta de uma grande llustração, que a nós e aos estrangeiros revele o que dentro de Portugal existe de bello, como creação do espírito, obra d'arte ou encanto da natureza, vem notando-se de há muito, sem que, no entanto, alguém se abalançasse aos sacrifícios e dificuldades de sua realização", pelo que "A CONTEMPORÂNEA Grande Revista llustrada, prestes a sahir a lume, vem preencher pela forma mais completa essa falta lamentável." Na mesma ocasião, a revista prometia, em pequenos folhetos, a publicação próxima de "primorosas folhas de arte a côres" (Daniel Pires et alii, Pacheko, Almada e "Contemporânea", Lisboa, Centro Nacional de Cultura-Bertrand Editora, 1993, pp. 257 e 259).

4 Entre os pintores e desenhadores das primeiras décadas do século XX que sobressaíram como ilustradores, podem recordar-se Rafael Bordalo Pinheiro, Cristiano Cruz, Leal da Câmara, Bernardo Marques, Stuart Carvalhais, Almada Negreiros, Julio, Tom (Thomaz de Mello), Jorge Barradas, António Carneiro, António 
são variadas, frequentemente de grande apuro, como muitos hors-textes publicados deixaram comprovado; em segundo lugar, pelo sortilégio da superação definitiva da sujeição da percepção à experiência directa, uma vez que a reprodução fotográfica passou a permitir tanto testemunhar factos históricos, num registo tido por transparente, quanto captar os segredos da sedução, do ideal, do exótico ou do atroz, numa palavra, a "ver a vida, ver o mundo";"; em terceiro lugar, pelo próprio desenvolvimento do grafismo, que se passou a distinguir pelas suas gramáticas apelativas, associadas à tradução imagética das orientações editoriais, à recriação específica das novas correntes artísticas e decorativas, à exploração surpreendente dos recursos de ilustração e de composição facultados pelo desenvolvimento das técnicas de impressão.

A variedade e o colorido das revistas foram acompanhados pela segmentação dos leitores, reflectida nos títulos - ou, mais frequentemente, nos subtítulos, que por norma os acompanhavam - através de determinativos que explicitavam os desígnios específicos que lhes presidiam. Desde a sua origem remota, a edição de cada título foi concebida como uma composição que interceptava géneros jornalísticos, literários e artísticos com interesses e gostos peculiares ${ }^{6}$. As revistas tenderam, assim, a ser publicações especializadas, fosse por se dedicarem a temáticas precisas (literárias, humorísticas, mundanas, doutrinárias, entre muitas outras), fosse por se dirigirem a públicos bem definidos (jovens, mulheres, homens de letras e crentes de uma confissão religiosa, por exemplo). É de notar que a diferenciação entre títulos se apresentou como característica de tal modo corrente que as próprias revistas de teor geral sentiram a

Pedro, António Soares e Roberto Nobre. É de notar que alguns escritores de destaque, como Jaime Cortesão, José Régio ou José Rodrigues Miguéis, também se aventuraram no domínio da ilustração.

5 A expressão é retirada do célebre artigo, e manifesto, em que a Life - a revista emblemática do fotojornalismo, que chegou a tirar oito milhões de exemplares - se apresentou, a 23 de Novembro de 1936, aos leitores e que merece transcrição por sintetizar o sentido geral da comunicação visual da vida que a reprodução fotográfica tornara possível:"ver a vida; ver o mundo; ser testemunha dos grandes acontecimentos; contemplar o rosto da pobreza e os gestos do orgulho; ver coisas estranhas - máquinas, exércitos, multidões, sombras na selva e na Lua -, ver o trabalho do homem, suas pinturas, torres e achados; ver coisas que ocorrem a milhares de quilómetros de distância, coisas ocultas e descobertas; coisas perigosas que estão para acontecer; as mulheres que amam homens e muitos filhos; ver e tirar partido do que se vê; ver e divertir-se; ver e ser instruído."

6 The Gentleman's Magazine, editado por Edward Cave Junior, em Londres, a partir de Janeiro de 1731 e ao longo de várias décadas, assinala-o no próprio título. Este último foi, aliás, acompanhado por vários subtítulos, como The monthly intelligences e Historical review. Pelo uso da expressão "magazine" para nomear a nova fórmula de periódico, pelo formato reduzido face à restante imprensa, pela periodicidade mensal e pela miscelânea criteriosa de assuntos, Edward Cave criou uma modalidade de imprensa que alcançou de imediato, dentro e fora de Inglaterra, fama e respeito, passando a ser amplamente imitada. 
necessidade de assinalar essa sua condição em subtítulo, ao indicarem a informação como o âmbito que as distinguia 7 .

O confronto com as outras modalidades correntes de edição permite, igualmente, caracterizar o âmbito próprio das revistas, ainda que algumas fronteiras entre géneros de imprensa apresentem zonas híbridas de sobreposição, mais ou menos extensas, e, por regra, fluidas, em conformidade, aliás, com os termos gerais da evolução de cada formato editorial e das sucessivas e profundas transformações que a comunicação social considerada no seu conjunto sofreu ao longo do século XX.

Quando comparadas com os jornais, as revistas podem distinguir-se pela periodicidade, o teor geral e o formato.

A vocação para a cadência diária está registada no próprio radical etimológico, proveniente do francês, do vocábulo "jornal." Destinado a proporcionar informação, o relato jornalístico vive do acontecimento próximo, da novidade, que, pela sua própria natureza, requer despacho e publicitação expeditos, motivo pelo qual os jornais consagrados, ao longo dos tempos e por todo o lado, são quotidianos, matutinos ou vespertinos, capazes de pôr em dia os seus leitores. Ora, a eventual existência de revistas diárias seria um contra-senso, de tal modo é claro que a urgência e a vertigem da informação jornalística contrastam com o escrutínio intencional e avisado, mais ou menos criterioso e reflectido, que as caracteriza.

A diferença de ritmo entre os jornais e as revistas, reflectida na periodicidade mais larga destas últimas, acompanha o teor dominante em cada um dos tipos de periódicos. Embora a informação e a opinião estejam presentes em ambos, a primeira foi, e é, preponderante nos jornais, enquanto a segunda prevaleceu, e prevalece, explícita ou implicitamente, nas revistas. Por outras palavras, as notícias fazem a matéria primeira dos jornais, enquanto, por regra, os artigos perspectivam e estruturam as revistas, preenchidas ainda por outros géneros jornalísticos, literários e artísticos.

É ainda possível reconhecer, por vezes ao primeiro olhar, alguns outros traços distintivos entre estes dois tipos de periódicos. Desde logo, o formato, que nas revistas foi desde sempre muito menor do que o dos jornais, mesmo dos tablóides, que redu-

\footnotetext{
Como aconteceu com a Time, que se apresentou, na sua edição inaugural, a 3 de Março de 1923, em Nova lorque, com o subtítulo Newsmagazine. É de notar que a Time criou um novo tipo de revista, em que os acontecimentos da semana são tratados, em secções fixas, de um modo que se pretende documentado, compreensivo e directo. A sua fórmula foi reproduzida por congéneres um pouco por todo o lado, ainda que, por vezes, com grande diferimento, como aconteceu, entre nós, com a Vida Mundial, criada na década de 1960. O formato das newsmagazines resistiu ao tempo e representa, desde a sua criação até à actualidade, uma parcela muito importante das revistas publicadas na América e na Europa.
} 
ziram a metade as dimensões correntes na imprensa diária. Outras diferenças físicas correntes já foram, implicitamente, sugeridas: a capa, presente nas revistas e ausente nos jornais; o formato de brochura das primeiras e o simples vinco central a unir as folhas dos segundos; o cuidado e a variedade postos na paginação das revistas e a monotonia tradicional da mancha dos quotidianos.

A caracterização das revistas face aos livros apresenta recortes ainda mais nítidos, uma vez que os livros são, em geral, publicações de autor, com arquitectura unitária, discurso uniforme, aspecto completo e definitivo.

Já a distância que separa as revistas dos boletins assenta numa disparidade fundamental: os boletins não são publicações autónomas, mas órgãos vinculados a instituições e, como tal, destinados à satisfação das suas finalidades estatutárias. Além de procederem ao relato da vida interna das organizações em que se integram, dividem-se, por regra, entre um modelo muito próximo do da revista temática e um formato editorial com orientação prática e mesmo com finalidades concretas.

Se, em nota geral, considerarmos as revistas, nomeadamente as das primeiras décadas do século XX, no quadro do conjunto das publicações da época, o aspecto editorial mais saliente é provavelmente o da graciosidade e da diversidade com que atraíram a atenção dos leitores. Este dom natural congénito, capaz de despertar curiosidade, de fomentar interesses e de fidelizar públicos, quer junto dos leitores de outros tipos de publicações, quer entre os que se lhes conservavam arredios, encontrou então condições culturais, técnicas e sociais excepcionais para se fazer sentir.

\section{Revistas e cultura}

No mundo contemporâneo, em que as sociedades passaram a observar-se a si próprias através da mediação da imprensa, o papel constitutivo das representações em que as comunidades vieram a reconhecer-se, e em muitos casos à luz do qual ganharam contorno e definição, foi desempenhado de forma muito relevante, ao longo de décadas sucessivas, por jornais e por revistas. Estas publicações periódicas não foram simples meios de circulação de informação ou de recreio, mais ou menos ilustrados, mas "suportes centrais do espaço público" e "mediadores essenciais das opiniões que se confrontam numa democracia"8, ou seja, actores situados no primeiro plano da vida colectiva, responsáveis tanto pela afirmação e confronto políticos, quanto pela identidade e devir culturais.

\footnotetext{
8 Christophe Charle, Le Siècle de la presse (1830-1939), Paris, Éditions du Seuil, 2004, p. 354.
} 
Dia a dia, os jornais criaram e reflectiram a realidade política?.

À escala pessoal, episódica e ressentida do preterido Brás Cubas, amparado no Humanitismo de Quincas Borba ${ }^{10}$, ou ao nível ambicioso e determinado da putativa representação de grandes desígnios sociais, nacionais e civilizacionais, os jornais, relativamente baratos e com tiragens muitíssimo elevadas ${ }^{11}$, foram a um só tempo arautos, organizadores colectivos, fautores da ordem do dia e instrumentos de combate no quadro de realidades políticas em que a opinião pública - frequentemente cindida, por seu intermédio, em facções opostas - e o sufrágio se haviam tornado decisivos.

Simultaneamente, as revistas reflectiram e criaram a realidade cultural.

Desfrutando de uma relação com o tempo diferente do tropel veloz dos diários, as revistas não se distinguiram por dar a ver, mas evidenciaram-se, antes, por rever, por reapreciar, à luz da fonte de sentido presente na orientação editorial de cada título, as realidades e os eventos do mundo que lhes era coetâneo.

Ao vencerem a prega de tempo necessária à depuração do quotidiano, estes periódicos trouxeram consigo as diferentes expressões e linguagens pelas quais o presente foi adquirindo consciência de si próprio: introduziram conceitos, fixaram temáticas, impuseram linguagens, defenderam teses, estabeleceram referências, instauraram símbolos, criaram mitos, desenharam o movimento das tendências e das modas.

A dimensão compreensiva foi-lhes intrínseca: cada título sintetizou, reformulou e actualizou os instrumentos intelectuais colectivos de que a sociedade, nas suas diferentes instâncias e grupos, dispunha para conferir significado ao evoluir contingente e inaudito do mundo e da vida.

Ora, se a cultura consiste no conjunto de representações colectivas que medeiam a relação dos homens uns com os outros e com o mundo, pelo qual estes conferem sentido à realidade e nela participam, as revistas não só foram poderosas fontes de elabo-

9 Rui Ramos assinalou-o: "a imprensa era o espaço público em que a sociedade e o Estado existiam, e estava para a vida política como a bolsa para a vida económica", pois "o que se dizia na corte, nos ministérios, nos quartéis, nas câmaras municipais, nas oficinas nunca se poderia tornar opinião importante se não fosse publicado nos jornais."Os jornais apareciam tão poderosos que não só "a principal organização dos partidos políticos eram os seus jornais, com a redacção a servir de sede", como também se investiam de finalidades filantrópicas e civilizacionais de monta (Rui Ramos, op. cit., pp. 56-57).

${ }^{10}$ Cf. Machado de Assis, Memórias Póstumas de Brás Cubas, Lisboa, Livros Cotovia, 2005, p. 292 e ss.

11 Em 1906, os onze quotidianos publicados em Lisboa somariam uma tiragem de aproximadamente trezentos mil exemplares diários (Rui Ramos, op. cit., p. 55), enquanto, na cidade-luz e durante a década de 1910, o Petit journal imprimia 1400000 exemplares, ascendendo a tiragem global dos quotidianos parisienses, todos com clara tendência ideológica, a uma cifra superior a 4700000 exemplares (cf. Chistophe Charle, op. cit., p. 156 e ss.). 
ração e de disseminação interpretativas, como também se revelaram particularmente pertinentes e acutilantes, na medida em que ergueram a sua discursividade - numa era em que a autoconsciência era valorizada e a mudança qualitativa tida genericamente por inevitável - a partir da reflexão sobre o fluir vivo dos acontecimentos.

A mediação cultural conheceu, naturalmente, diferentes escalas, em conformidade com os públicos a que cada publicação se dirigia. Porém, a dimensão global de que se revestia não necessitava, à excepção das revistas doutrinárias ou científicas, de garantir sistematicidade ou radicalidade, antes bastava assegurar correspondência entre os tópicos presentes no horizonte de interesses e de referências dos leitores visados e as matérias publicadas.

O protocolo almejado entre a publicação e o seu público seria aquele que fizesse com que os leitores reconhecessem na publicação um símile do seu próprio mundo, ou de uma sua parcela relevante, ao encontrarem nas suas páginas, de forma acessível, amena e variada, como se de um bazar ou depósito ${ }^{12}$ da vida se tratasse, repositórios das matérias e das evocações que julgavam merecer consideração, justificar curiosidade, proporcionar satisfação.

A escolha de perspectivas de abordagem, formatos, temáticas, registos, organização em secções permanentes subordinou-se, pois, ao desígnio de padronizar a relação entre a natureza e a estrutura da publicação e o perfil peculiar dos seus destinatários, de modo não só a facultar o reconhecimento de afinidades relevantes, mas também a conferir-lhes expressão conjunta e facetada. Cada título encerrou, assim, uma visão e uma atitude face ao mundo, uma cosmovisão particular, feita da adição das manchas fragmentadas com que a realidade, ou uma sua parcela significativa, daqueles a quem se dirigia era feita.

Como o relacionamento entre os leitores e os títulos em que cada um revia a sua imagem da realidade ocorreu nas revistas de forma regular e perdurável no tempo, frequentemente ao longo de anos sucessivos, a mediação que estas proporcionaram não se desenvolveu de forma circunstancial e incerta.

Estas publicações não trouxeram à vida a iluminação de um livro tocante, o êxtase de uma récita sublime, a graça de uma representação inesquecível, o deslumbramento

12 O vocábulo "magazine", utilizado em Inglaterra desde meados do século XVIII para designar as primeiras revistas, tem origem na palavra francesa "magasin", a qual provém, por sua vez, do vocábulo árabe "makhazin", plural de"makhzin" (armazém de qualquer tipo). 
de um filme emocionante, mas a trama de uma relação ratificada regularmente, de acordo com a cadência de edição do periódico.

Os títulos da inclinação de cada leitor proporcionam, assim, um envolvimento prolongado, a seu modo folhetinesco, feito tanto de atenção e leitura quanto de simpatia e afecto. A proximidade, originada num primeiro momento pela atracção resultante de afinidades reconhecidas, consolidava-se e estruturava-se depois através de corroboração contínua e regular. Prolongava-se, renovava-se e ampliava-se, em cada nova edição, frequentemente aguardada com expectativa. O cômputo geral superava, então, o somatório fátuo de matérias aparentemente episódicas para se adensar em concepções e quadros de referência estáveis, adoptados muitas vezes como o fundamento de um olhar consolidado e próprio, tido por esclarecido, sobre os homens, os livros e as coisas.

Se cada título, considerado em cada uma das suas edições, invariavelmente datadas, parece (na sua aparência imediata, tanto pela forma física quanto pela variedade e dispersão circunstanciais) uma publicação efémera, já o efeito da sucessão das edições (designadamente se associada ao cultivo continuado de interesses, incluindo os espirituais, que proporcionam aos seus leitores) deixa de o ser, de tal modo a afirmação e a evolução das revistas pressupõem um mínimo de coerência conceptual, temática, valorativa e imagética, mesmo naqueles casos em que foi pela frivolidade e banalidade mundanas que se distinguiram.

O facto de cultura e cultivo caminharem neste caso, como na generalidade das situações, a par, ainda que no âmbito das revistas com ritmo predefinido e preciso, bem como a circunstância de perspectivarem a realidade de forma situada não significa que a sucessão das edições se limite ao desdobramento rígido e sequencial das disposições que lhe serviram de matriz.

O olhar inicial de cada título sobre a realidade que por seu intermédio se deixaria decifrar facilmente passa, com o correr dos anos, da nitidez pertinente e persuasiva à caducidade capciosa, caso não reactualize pressupostos, abordagens e linguagens.

As revistas, ao nomearem e dizerem o mundo, conheceram os diferentes ritmos dos seus ciclos de vida: a erupção oportuna e surpreendente que, pela sua qualidade, alterou o clima cultural dos leitores e, mesmo, do país esclarecido; o trânsito ardente de um período decisivo; a emoção evanescente de uma moda; o acompanhamento marcante e prolongado de situações culturais e históricas estáveis; a afirmação, intermitência e reformulação em diferentes séries; o arco temporal centenário, inerente à 
sedimentação do título junto de um público estável; o declínio prolongado, em consequência da denegação da caducidade ingrata do programa prosseguido.

No seu conjunto, as revistas formaram, assim, um painel panorâmico, sincrónico e diacrónico da cultura viva, decerto o seu registo mais significativo na época considerada, dando a conhecer o sentido das suas expressões e dinâmicas.

Isoladamente, alguns títulos duradouros possibilitam captar os próprios sentidos das transformações culturais, na medida em que as suas edições as integraram e reflectiram, assemelhando-as assim a fotogramas, cada um, por si, estático, mas na sua sucessão claramente cinemáticos, ao revelarem o movimento das diferentes realidades com que preencheram as suas páginas.

O mérito cultural atribuível a cada título minimamente significativo pode ser aferido a partir de dois critérios fundamentais: o da consistência, qualidade e originalidade, ainda que relativa, dos materiais publicados e o da relevância assumida nas transformações da percepção social do mundo e da vida.

A propósito do primeiro destes critérios, é de referir que mesmo títulos apreendidos à boca da tipografia tiveram o merecimento necessário, apesar de não haverem chegado às mãos dos leitores, para passarem a indicar marcos na história das letras e das artes nacionais ${ }^{13}$.

Acreditava-se, em geral, no valor demiúrgico do pensamento, no papel revolucionário das ideias, na verdade definitiva do saber científico, na magnanimidade das letras, na inefabilidade das artes, na necessidade imperativa da modernidade.

Acerca do segundo critério, é de sublinhar que a própria imprensa de natureza comercial se dizia subordinada à missão intelectual e civilizacional de reformar mentalidades e de promover conhecimentos úteis, prolongando e ampliando o espírito oitocentista de "amor da instrução"14.

${ }^{13}$ Como Portugal Futurista (1917) e Cadernos da Juventude (1937), mais tarde reeditados e frequentemente evocados.

${ }^{14}$ Alexandre Herculano deixou-o sublinhado logo na apresentação do número inaugural do célebre O Panorama - Jornal Literário e Instructivo da Sociedade Propagadora dos Conhecimentos Úteis, editado a 6 de Maio de 1837:"neste estado da ilustração e do progresso o que mais importa é o dilatar por todas as nações, e introduzir em todas as classes da sociedade o amor da instrução; porque este é o espírito do nosso tempo, porque esta tendência é generosa e útil" (O Panorama, 1837, p. 1). Patrocinado por Dona Maria Il, o periódico foi dirigido na fase inicial dos seus dezoito anos de publicação, distribuídos por cinco séries, entre 1837 e 1868, pelo autor de O Monge de Cister, romance parcialmente publicado nas suas páginas, tendo obtido, com os quase cinco mil exemplares de tiragem e com a colecção de livros que lhe esteve associada, um êxito significativo, embora muito menor do que o alcançado pela revista inglesa Penny Magazine, com tiragem de trezentos mil exemplares, tomada expressamente por modelo (cf.ibidem, p. 53). 
A obrigação de providenciar a difusão científica, histórica, literária e artística, de difundir informações e conselhos profilácticos, domésticos e técnicos, de colocar a nação a par do mundo civilizado representaria dever comum e indeclinável de toda a imprensa. Esta missão definiria mesmo a grandeza da tarefa histórica e social que reclamava para si e em que gostava de se rever com notória boa consciência.

Instrução e imprensa foram, aliás, realidades próximas e correlativas. A imprensa afirmou-se na medida em que a instrução pública alargou o universo dos leitores, contributo que retribuiu ao chamar a si um papel supletivo de fomento educacional. Os jornais e as revistas dirigiam-se, em primeiro lugar, à classe média, letrada e com posses, fomentada pela diferenciação e pela mobilidade sociais inerentes à escolarização. Em sentido complementar, os homens de imprensa e os restantes publicistas deviam à instrução, escolar ou autodidacta, as competências de redacção e de tradução que os qualificavam, Ihes conferiam estatuto e facultavam modo de vida.

No quadro de um imaginário centrado nas expectativas depositadas na divulgação social das luzes, na redescoberta da autenticidade colectiva, na formação do cidadão esclarecido e empreendedor, escola e imprensa ocupariam papéis complementares e decisivos na edificação das consciências e das almas, no renascimento da nação e no progresso da civilização.

A simpatia e o empenho colocados na promoção da ilustração pública, assente na cultura do escrito e muito distinta da criação da chamada cultura de massas - associada aos imaginários suscitados e suportados por novos meios de comunicação, como a rádio e o cinema, em que as revistas também desempenharam papel de monta -, trouxe consigo uma notável revitalização da vida cultural, na dupla dimensão criativa e de divulgação.

O número de revistas e de outros periódicos literários portugueses, ou com componente literária, criados e publicados ao longo dos três primeiros quartéis do século XX exemplifica-o cabalmente: 275 novos títulos, 25 por ano, em média, nos onze anos compreendidos entre 1900 e 1910; 483 títulos, trinta por ano, em média, nos dezasseis anos que vão de 1911 a 1926; 439 títulos, nove por ano, em média, nos 48 anos do Estado Novo ${ }^{15}$.

${ }^{15}$ Cf. Daniel Pires, Dicionário da Imprensa Literária Portuguesa do Século XX, Lisboa, s. d., vol. I, p. 375 e ss.; vol. II, 2. ${ }^{\circ}$ tomo, p. 635 e ss. Daniel Pires utilizou um critério relativamente abrangente, assente na selecção de revistas e de outros periódicos, a partir da publicação regular e significativa, nas suas páginas, de textos ou de temas literários. Com escrutínio mais restrito, numa "perspectiva selectiva e não sistemática,"no que respeita à relevância literária e cultural das revistas seleccionadas, Clara Rocha analisou número inferior 
As estimativas que se podem fazer para os inventários de revistas de outros domínios temáticos, designadamente a partir da consulta de repertórios e de catálogos, apontam igualmente para números de títulos novos e de publicações em circulação considerados, tanto em termos absolutos quanto relativos, muito relevantes ${ }^{16}$.

É igualmente de recordar quer a circunstância de muitas revistas terem estendido o seu múnus à edição de livros (como aconteceu, por exemplo, com A Águia, que ficou associada à publicação de três centenas de obras), quer as afinidades entre algumas colecções de livros de divulgação (incluindo a célebre "Biblioteca do Povo e das Escolas", distribuída em Portugal e no Brasil) e as temáticas e linguagens presentes na vertente de divulgação de conhecimentos dos periódicos de que nos ocupamos, que, a seu modo, retomavam, desenvolviam e completavam.

Todo este vasto esforço de criação e de divulgação culturais, que teve nas revistas um instrumento privilegiado, foi potenciado e ampliado pela dimensão internacional de que se revestiu.

Esclarecimento racional e subtileza intelectual, expressividade literária e artística, progresso civilizacional e técnico, emancipação humana e social, gosto e moda requintados não representavam valores de extracção vernácula, mas bens irradiados a partir das grandes capitais.

O sentimento de modernidade encontrou nas revistas de vocação internacional os seus mercúrios universais. Por seu intermédio, a vida festiva de Paris, o conservadorismo imperial de Londres, a turbulência de Nova lorque ou o firmamento de Hollywood passaram a ser realidades familiares.

Universalidade, modernidade e cosmopolitismo tornaram-se, então, equivalentes.

de revistas: dezoito novos títulos surgidos entre 1900 e 1910; 45 entre 1911 e 1926; 129 entre 1927 e 1974 (cf. Clara Rocha, Revistas Literárias do Século XX em Portugal, Lisboa, Imprensa Nacional-Casa da Moeda, 1985, p. 635 e ss.). Acerca da edição de novos periódicos durante os anos do Estado Novo, é de sublinhar que as restrições à liberdade editorial eram anteriores à própria possibilidade do exercício da censura, pois os entraves políticos e administrativos colocados aos candidatos a proprietários e a directores de novos títulos foram sempre muitos e variados, a ponto de estes se terem visto, com muita frequência, na necessidade de os contornar através da aquisição ou da tomada de publicações já existentes.

${ }^{16}$ António Nóvoa e Filomena Bandeira incluíram 530 periódicos editados em Portugal, na maioria com o teor próprio das revistas, no Repertório da Imprensa de Educação e de Ensino, dos séculos XIX e XX, ao mesmo tempo que inventariaram, no Catálogo de Imprensa de Educação e Ensino, 2306 publicações. $O$ Repertório resulta da aplicação de um critério de conteúdo, ao reunir as publicações que dedicaram mais de um quarto das suas páginas a temas pedagógicos e educativos, enquanto o Catálogo resulta da aplicação de um critério de contexto, ao abranger as publicações de instituições e grupos associados ao ensino (António Nóvoa, Evidentemente. Histórias da Educação, Porto, Edições ASA, 2005). 
A Revue des deux mondes, uma das publicações internacionais mais antigas, fundada em 1829, muito lida e conceituada na velha Europa e no Novo Mundo ao longo de décadas sucessivas, gravou o intento cosmopolita que lhe presidia no próprio título, evocativo do propósito de aproximar os leitores cultos dos dois continentes tidos por civilizados.

Apesar de a limitação inerente ao obstáculo de os segmentos do público versados em idiomas estrangeiros serem reduzidos, as revistas com vocação internacional conheceram, em muitos casos, grande receptividade, sem equivalência entre outro tipo de publicações, o que permite não só explicar que se encontrem, no decorrer do século XX, muitos magazines com circulação à escala mundial, como justificar a publicação de um mesmo título em várias línguas ${ }^{17}$, por vezes em edições locais e com matéria editorial específica.

O sentimento e o perfume cosmopolitas impregnaram igualmente os títulos nacionais mais vincadamente urbanos, que se queriam arejados e responsavelmente avançados, numa palavra, desejosos de acompanhar o mundo e as suas novidades. Embora muitas revistas tenham conservado os formatos correntes e locais, muitas outras distinguiram-se tanto por se moldarem segundo padrões internacionais, quanto por rasgarem as janelas pelas quais os leitores passaram a vislumbrar a vida mundial. No programa editorial, nos critérios temáticos, nas opções gráficas, no imaginário simbólico, nas traduções, nas referências explícitas, no ardor posto na defesa de convicções e na frivolidade da high life, estes títulos importaram e assimilaram as novidades dos grandes títulos estrangeiros.

Curiosamente, algumas das publicações periódicas que se destacaram na defesa do tradicionalismo não deixaram de se revelar miméticas das suas congéneres europeias, ao reconstituírem os mitos nacionais segundo modelos e práticas alheios.

A dificuldade em captar a pluralidade das dimensões culturais em que as revistas fizeram sentir o papel primordial que ocuparam na circulação de representações, símbolos e valores, ao longo do século considerado, resulta quer da complexidade ínsita em todas as grandes inflexões culturais e das mentalidades (produtos da sobreposição de várias malhas de vínculos independentes, muitas vezes invisíveis e tácitos), quer da difícil consideração da sua articulação com a mudança acelerada e geral da vida e do mundo, presentes, por exemplo, na escala universal da revolução urbana e no progressivo desenvolvimento dos sectores terciários da actividade económica.

17 A Reader's Digest, traduzida em 35 línguas e com distribuição em 120 países, com vendas globais próximas dos trinta milhões de exemplares, através de assinatura, numa parte substancial, constitui provavelmente o exemplo mais eloquente do sucesso, ao longo de muitas décadas, de uma publicação periódica com vocação mundial. 
Embora a objectivação do lugar concreto das revistas na inflexão das mentalidades e no comportamento individual e colectivo se revele muito frequentemente problemática, a aceitação do alcance cultural de que o seu papel se revestiu, bem como dos seus grandes sentidos, parece dificilmente iludível.

\section{Revistas de ideias}

Num contexto mundial em grande convulsão, de que as duas grandes guerras foram os expoentes, atravessado pelos conflitos inerentes à "questão social" (a que a Revolução de Outubro e a política de blocos deram expressões institucionais), marcado pela rápida afirmação de novas capacidades técnicas (como a magia da electricidade, do telefone, do cinema, da telefonia e da televisão exemplificaram) e revolvido pelas mudanças de costumes, linguagens e gostos, que a simples evocação dos anos 20 ou 60 passou a assinalar, o papel desempenhado pelas revistas, como meios de comunicação que simultaneamente reflectiram a mudança e sedimentaram as diferentes expressões da apreensão colectiva da vida e do mundo, não se confinou ao teor específico da esfera jornalística e aos formatos empresariais da imprensa periódica, mas estendeu-se, de forma igualmente muito vincada, aos domínios do conhecimento e da afirmação doutrinária.

Para além da publicação regular dos antigos e dos novos títulos em que o mundo académico, bem como a orla daqueles que lhe eram próximos, dava a conhecer o saber e as novidades disciplinares (cujo interesse, em domínios como a História, a Geografia, a Etnologia, a Filologia, a Filosofia, por exemplo, extravasava o universo da respectiva comunidade especializada), encontramos muitos outros títulos com elaboração cultural exigente e apurada, por regra com natureza claramente doutrinária, subordinados ao desígnio da elaboração e da divulgação da consciência esclarecida do tempo presente, da qual se fazia decorrer, naturalmente, o dever de intervir activamente nas decisões colectivas.

Sendo os homens de letras, do pensamento e das ciências encarados como os símbolos vivos do saber e este concebido como a alma e a matéria do elã libertador contemporâneo, com provas dadas, quer no domínio da edificação voluntária e constitucional da cidade, quer no âmbito da libertação de enleios naturais, o estatuto de que escritores e cientistas desfrutavam e as expectativas que se depositavam na sua ilustração tornaram-se muito elevados.

As figuras da cultura catalíticas desta dimensão emblemática ganharam assim a condição, informal mas corrente, de autoridades tutelares, não só no âmbito espe- 
cífico da actividade em que cada uma tinha revelado o seu mérito, mas também de forma indiscriminada e genérica.

Este prestígio lato, a seu modo olímpico, prolongava, na actualidade, a linhagem extensa dos heróis modernos da cultura, de Galileu a Darwin, de Voltaire a Zola, inscritos numa perspectiva geral do percurso humano em que o esclarecimento racional e a integridade espiritual e altruísta eram concebidos como evoluindo a par.

Pressupunha-se, em consequência, que a condição de homem culto traria consigo uma ética cívica.

Os imperativos que obrigariam as pessoas esclarecidas face aos seus concidadãos dirigir-se-iam em dois sentidos fundamentais.

Acreditava-se, por um lado, que o poder das luzes residia na sua propagação, pois a divulgação universal do saber era condição da constituição da comunidade política, uma vez que a cidadania pressupunha o discernimento individual autónomo, factor de salvaguarda do bem comum (na medida em que facultaria o escrutínio colectivo da vida comunitária) e aspecto determinante do fomento material, pela aplicação industriosa do saber disseminado. As missões civilizadoras atribuídas ao ensino público obrigatório e à imprensa em geral, já referidas, espelhavam esta convicção, que as muitas revistas e outras publicações dedicadas, exclusiva ou parcialmente, à divulgação cultural, científica e de conhecimentos úteis tomaram igualmente como escopo próprio.

Sentia-se, por outro lado, que quem sabia, por estar mais preparado para ver, ouvir ou ler, não podia deixar de intervir na cidade. Abster-se de o fazer representaria conivência culposa e infame.

Investidos na condição de representantes vivos do saber, os autores consagrados estavam em condições de agir em nome dos grandes valores civilizacionais, como a verdade e a justiça, de que seriam os fiéis depositários, desfrutando assim de um ascendente que os elevava à condição de efectiva consciência colectiva, alheia e superior aos jogos retóricos e de poder dos agentes políticos.

Os intelectuais, como realidade colectiva, desempenharam, então, um papel central na formulação, divulgação e debate das ideias e das concepções que atravessaram o conjunto do mundo ocidental.

Poucos anos antes da viragem para o século XX, Eça havia declarado ser Portugal,"na Europa, o único país que não possui uma Revista"18, ao expor o programa da Revista de Portugal, que fundou e dirigiu entre 1889 e 1892. A seu ver, os periódicos deste

${ }^{18}$ Revista de Portugal, Porto, Editores Lugan \& Genelioux, 1889, p. 3. 
tipo, então existentes, não satisfaziam "as curiosidades intelectuais que uma cultura crescente torna felizmente cada dia mais largas e múltiplas"19, sendo o público"prejudicado quando, pela falta de uma Revista onde esses trabalhos [romances, poesia, crítica literária, História, Filosofia, Sociologia, apreciação de actos legislativos, análise dos problemas nacionais, comentários do estado político, entre outros domínios] se produzam, não possa aproveitar do ensino, do conselho e da luz que eles contenham"20. Para os autores seus contemporâneos, a ausência sentida seria igualmente nefasta, pois "tem da falta de uma Revista resultado esta desunião moral e intelectual que nos traz dispersos, como divorciados"21, situação que a publicação do periódico almejado permitiria superar, ao "estabelecer um centro intelectual onde os escritores vivam uns com os outros em mais estreita comunhão"22. Comunhão que Eça queria ampla, já que pretendia congregar, na revista que anunciava, "uma numerosa e ilustre plêiade de espíritos, a mais bem dotada e brilhante que jamais reuniu uma publicação em Portugal", dada a conhecer desde logo na lista de trinta e oito "colaboradores efectivos" do novo título, em que figuravam os autores mais salientes da sua geração e daquela que se lhe seguiu ${ }^{23}$.

Embora Eça tenha afirmado, no folheto programático previamente divulgado, que "a Revista de Portugal, sendo portuguesa, é também implicitamente brasileira - e para a leitura dos dois povos que habitam os dois solos foi ela desde princípio criada"24, a carta-circular distribuída na mesma ocasião, igualmente da sua autoria, faz convergir os diferentes desígnios enunciados para o objectivo de despertar e de exercitar a actividade de produção de ideias nacional, de "'acordar' Portugal, colocando-o ao nível dos restantes países europeus, não pela economia, mas pelas ideias culturais, filosóficas e científicas que podia produzir"25.

A missão histórica e cívica a que os homens de letras se diziam vinculados atravessou, em Portugal como na generalidade do Ocidente, o conjunto da centúria áurea

\footnotetext{
19 Ibidem, p. 4.

20 Ibidem, pp. 6-7.

${ }^{21}$ Ibidem, p. 7.

22 Ibidem, p. 8.

${ }^{23}$ Basta atender a um terço dos nomes da lista de "colaboradores efectivos" - Antero de Quental, Oliveira Martins, Ramalho Ortigão, João de Deus, Sampaio Bruno, Guerra Junqueiro, Jaime Batalha Reis, Teófilo Braga, Pinheiro Chagas, Conde de Ficalho, Luís de Magalhães, Moniz Barreto e Jaime Moniz - para se verificar que a Revista de Portugal tinha a ambição de ser o órgão da intelligentsia nacional.

24 Ibidem, p. 11.

25 Miguel Real, O Último Eça, Matosinhos, QuidNovi, 2006, p. 145.
} 
das revistas, pois todos aqueles que julgavam trazer à comunidade uma novidade doutrinária emancipadora ou que sentiam, simplesmente, a obrigação de fazer sentir a presença da reflexão avisada, da cultura informada e da vigilância crítica no quotidiano colectivo acabaram por fundar e colaborar em revistas de ideias.

A Seara Nova, revista quinzenal de doutrina e crítica pode ser tomada como exemplo do desiderato persistente que tinha animado, três décadas antes, Eça e os seus antigos e novos companheiros de intervenção pública.

O retrato de grupo dos fundadores da publicação é bem conhecido, ao incluir alguns dos autores mais prestigiados da cultura portuguesa nos domínios da literatura (Raul Brandão e Aquilino Ribeiro), do jornalismo e do pensamento (Raul Proença), da investigação histórica (Jaime Cortesão), da nova pedagogia (Faria de Vasconcelos), a que muitos outros homens do saber se somaram, como, por exemplo, António Sérgio, Ferreira de Macedo, Ezequiel de Campos e o jovem José de Azeredo Perdigão.

A exposição do programa do quinzenário, na sua edição inaugural, publicada em 15 de Outubro de 1921, apresenta-se, logo no parágrafo inicial, inequívoca, quer a respeito das motivações de protesto cívico e das finalidades de reforma social e política esclarecida que lhe presidiam, quer acerca da relevância conferida aos intelectuais na regeneração da República ${ }^{26}$.

Ao invés da breve Revista de Portugal, que desfaleceu no quarto ano de publicação, a Seara Nova distinguiu-se pela tenacidade, pois conheceu 1599 edições, entre 1921 e 1979, por vezes com periodicidade semanal, a que ficou associada, ainda, actividade editorial muito relevante na publicação de livros, bem como numerosos ciclos de conferências e de outras iniciativas variadas de difusão cultural e doutrinária.

A estas duas revistas, somaram-se centenas de outros títulos com fins semelhantes, cobrindo reiteradamente todo o espectro do debate de ideias e da intervenção política, social e cultural que coloriu, segmentou e animou tanto o mundo contemporâneo como a sociedade portuguesa.

Porém, a representação do dever cívico que conduziu à publicação de cada revista não se apresentou uniforme, pois oscilou entre o proselitismo doutrinário de teor polí-

${ }^{26}$ Escreveu Raul Proença, em nome do Grupo Seara Nova: "a Seara Nova representa o esforço de alguns intelectuais, alheados dos partidos políticos mas não da vida política, para que se erga, acima do miserável circo onde se debatem os interesses inconfessáveis das clientelas e das organizações plutocráticas, uma atmosfera mais pura em que se faça ouvir o protesto das mais altivas consciências, e em que se formulem e imponham, por uma propaganda larga e profunda, as reformas necessárias à vida nacional" (Seara Nova, n. ${ }^{\circ} 1,15.10 .1921$, p. 1). 
tico, social, estético, ideológico e confessional e a missão civilizadora da divulgação e da actualização culturais e a intervenção regular, concreta e próxima na vida comum, mais ou menos casuística.

Simultaneamente, o papel representado pelas revistas na constituição dos grupos de intelectuais e no desempenho das missões em que estes se sentiam investidos não conheceu excepções ou variações significativas, de tal modo a publicação periódica de ideias elaborada conjuntamente ocupou, por regra, o lugar central, estruturante e determinante nos movimentos de intelectuais que venceram a condição de fogaréu circunstancial.

Fazer uma revista era, antes de mais, erguer a tribuna que permitia que aqueles que sentissem ter algo de novo ou de relevante a dizer o fizessem, pois foi o meio mais eficaz, ao longo de muitas décadas, para conferir realidade à afirmação pública e continuada de convicções doutrinárias e dos ditames interventivos que lhes estiveram associados.

Eça, nas passagens do Programa da Revista Portugal transcritas, deixou-o sugerido, ao indicar que as revistas são centros intelectuais onde os escritores vivem uns com os outros em estreita comunhão, o que lhes permitiria vencer a desunião moral e intelectual que a sua falta provocaria.

A simples recapitulação mental dos grandes títulos internacionais e nacionais que preencheram a exposição e o debate de ideias públicos, década após década, permite, a quem conheça minimamente o período considerado, imaginar os escaparates de uma boa livraria como dois fora paralelos, um europeu e outro local, em que as grandes correntes doutrinárias se encontravam expostas e os seus principais defensores acantonados, tomando as respectivas revistas por bandeiras e as grandes teses propaladas como dispositivos de afrontamento, simultaneamente mundial e civil, dos espíritos que se queriam esclarecidos, hodiernos e empenhados na defesa de interesses comuns.

Todas as grandes correntes ideológicas, políticas e culturais tiveram as suas revistas, pois a falta de tribuna própria para a produção e divulgação doutrinárias significava ficar excluído do certame colectivo das ideias e concepções, exactamente no momento em que estas eram celebradas como guias indeclináveis da acção individual e colectiva, tão urgente quanto promissora, mesmo deslumbrante.

Quem conheça minimamente o período considerado não pode deixar de identificar, nos domínios da literatura e das artes, os periódicos de realistas, simbolistas, academistas, modernistas (segundo diferentes programas), neo-realistas e surrealistas (de 
outras sensibilidades com poéticas peculiares); no domínio do pensamento político, os títulos monárquicos e constitucionalistas, republicanos, integralistas e legitimistas, nacionalistas, socialistas, libertários, anarco-sindicalistas, democratas-cristãos, corporativistas, cooperativistas, marxistas, liberais e radicais; no domínio confessional, as revistas defensoras da doutrina social da Igreja, neotomistas, conciliares, bem como, em sentido oposto, as de teor anticlerical; a que é necessário acrescentar muitos outros títulos em variados domínios do pensamento e do saber, bem como aqueles cuja idiossincrasia e, por vezes, eclectismo tornam difíceis de qualificar sumariamente, embora a orientação a que obedeceram e o papel que desempenharam no debate de ideias tenham sido claros e relevantes, como aconteceu, por exemplo, com A Águia e a Seara Nova (o que motiva que a primeira surja, por norma, associada ao programa da Renascença Portuguesa e ao "saudosismo", enquanto a segunda esteja na origem do uso corrente do vocábulo "seareiro", não no sentido lato e metafórico de propagador de ideias e doutrinas, mas com o significado específico de autor ou de defensor das concepções expostas na revista que Raul Proença e António Sérgio dirigiram).

Mesmo um relance simples e sumário sobre os títulos agrupados segundo as orientações que lhes presidiram, como as enunciadas, suscita a necessidade de reflexão sobre o papel desempenhado pelas revistas na constituição dos movimentos de intelectuais e nas modalidades de circulação de ideias e concepções no âmbito do que poderíamos classificar como espaço público doutrinário.

O esboço do esclarecimento destes dois aspectos indissociáveis e centrais na história cultural e política recente pode ser delineado segundo critérios que considerem as revistas de ideias e doutrinas sob cinco linhas de perspectivas principais: como norte e campo magnéticos que polarizam e agregam redactores e colaboradores, conferindo-Ihes uma identidade colectiva; como espaço de auto-revelação e concretização doutrinárias, ao metamorfosearem simpatia programática em pensamento e acção concretos; como conjugação entre a unidade de propósitos e a pluralidade de vozes e registos, em que um conceito de saber próprio encontra a sua expressão; como trajectória do fluir temporal das concepções perfilhadas, patente no fio das inflexões de teor que necessariamente atravessam a sucessão das edições; como empreendimento que procura produzir um efeito social, o que determina que pensamento, pragmática e estratégia surjam, entre si, combinados.

As revistas de ideias foram, pela sua própria natureza, empreendimentos colectivos subordinados a um propósito editorial comum e, como tal, instrumentos particularmente adequados para facultar expressão comum a grupos de intelectuais, os quais 
ultrapassaram, por seu intermédio, o foro da opinião singular para adquirirem voz e autoridade conjunta. Face a outras modalidades de intervenção cívica - petições, provocação de factos simbólicos, constituição de grupos de pressão, actividade associativa, iniciativas institucionais -, estes periódicos apresentaram tanto a vantagem inerente à publicitação regular de uma mesma causa, quanto os inconvenientes resultantes da rigidez do formato e da periodicidade predefinida.

A passagem da intenção à explicitação programática e da orientação e finalidades proclamadas às expressões editoriais concretas que conferiram realidade às revistas não consistiu, por regra, num simples exercício dedutivo, mas antes num conjunto de tarefas desdobradas no tempo, pelas quais os redactores descobriram e revelaram o teor efectivo da sensibilidade, do pensamento e dos propósitos, individuais e colectivos, próprios. Mesmo nos casos em que a dimensão receptiva de um pensamento alheio ou de uma escola cativante prevaleceu sobre qualquer outro aspecto, a formação cultural dos articulistas - as referências idiossincráticas em que se moviam, a sensibilidade aos interesses em jogo, os crivos de critérios próprios - foi determinante para o teor da publicação ficar vinculado à interpretação particular que acompanha qualquer adesão, mesmo quando esta se apresentava com a candura irreal da transparência. As revistas marcantes constituíram o espaço e a oportunidade de redactores e colaboradores unidos por um mesmo propósito, quando tocados pela argúcia e pelo talento, firmarem, singular e conjuntamente, tanto os contornos das diferentes expressões de um pensamento peculiar, quanto a concretização da intervenção efectiva na vida da cidade. Subsumir a identidade de uma revista à letra do programa editorial inicial, embora a relevância do documento fundador se apresente quase sempre patente, é uma redução simplista, a que escapa a matéria efectiva que conferiu identidade, realidade e sentido ao pensamento e à acção próprios.

$\mathrm{Na}$ amplitude da variedade de vozes chamadas a redigir e a colaborar num mesmo título e na paleta dos diferentes registos em que o seu teor se expôs, encontra-se a matéria que permite apreciar, na maioria dos casos, o conceito de saber que lhe deu forma. $O$ esclarecimento deste conceito é relevante: mostra a concepção do mundo e o sistema de valores que fundamentaram o propósito e o teor da publicação, esclarece a natureza do vínculo que uniria esclarecimento e acção e contém, implícita ou explicitamente, o fundamento do mérito social atribuído à cultura e aos seus agentes. Em contexto de conflito de ideias e doutrinas, todo o eclectismo apresentou margens mais ou menos estritas, conformes ao âmbito da representação própria dos limites do saber verdadeiro e pertinente. Uma vez que cada revista foi, pela sua própria natu- 
reza, produto de um propósito editorial que lhe conferiu unidade e simultaneamente expressão da pluralidade das manifestações em que este se desdobrou, a observação de cada publicação a partir da relação que vinculou a unidade programática à diversidade do material publicado torna-se relevante para a compreensão da sua identidade efectiva. É de atender, desde logo, ao tom geral de cada título - doutrinário, de divulgação científica, literário, social, político, confessional -, já que há uma relação solidária e recíproca entre a natureza do saber a propagar e os propósitos pretendidos. Os impulsos para a divulgação humanista, científica ou de ideias resultam de concepções com pressupostos entre si muito distintos, embora sobreponíveis e com relações frequentemente complexas (como, por exemplo, as revistas neo-realistas atestaram, ao servirem de órgãos a um movimento declaradamente literário e artístico e ao distinguirem-se pela publicação muito escassa de produções destes âmbitos). O espectro de géneros e de temáticas publicados regularmente, normalmente distribuídos por diferentes secções estáveis, revela a economia interna da concepção que presidiu à publicação, a importância relativa conferida aos diferentes domínios de que se ocupou, bem como os limites, isto é, a relação de inclusão e de exclusão, a diferentes títulos, próprios.

É igualmente de sublinhar que as revistas de ideias deram a conhecer, a partir das mudanças observáveis na sucessão das edições, o próprio trajecto do pensamento a que conferiram, com plasticidade e rigidez variáveis, da ancilose à metamorfose, realidade. Os títulos mais significativos das diferentes correntes de intelectuais constituem, por regra, registos fiéis dos trilhos culturais e cívicos que estas percorreram. A leitura diacrónica de cada um destes órgãos programáticos torna possível surpreender quer a agregação, dissidência e recomposição do núcleo de autores que atraíram, quer o movimento das ideias e das concepções que caracterizaram o fluir da orientação cultural e cívica a que deram expressão pública. Trata-se, frequentemente, de pequenas deslocações que só revelam todo o seu alcance quando consideradas através do resultado do seu somatório: alterações no destaque relativo das secções em que a publicação se dividia, inflexão nas temáticas abordadas, desuso progressivo de algumas noções e introdução de novas linguagens, revisão do panteão simbólico, adição de novas referências, desdobramento do programa inicial em corolários inéditos, alterações nas tonalidades de gosto e dos sentimentos predominantes. Nas revistas publicadas durante períodos muito longos ou que apresentaram várias séries, as mudanças temáticas, conceptuais e imagéticas ganharam, frequentemente, nitidez explícita, expressa em diferentes ciclos editoriais e distintos episódios de refundação, 
com as consequentes revisões programáticas e editoriais, introduzidas por novos corpos directivos e redactoriais.

Tratando-se de revistas de pensamento e de acção, como se dizia no subtítulo de O Tempo e o Modo, estes periódicos expressavam tanto a orientação geral que lhes presidia quanto o esforço de concretização dos desideratos por que propugnavam. Aos redactores e colaboradores conferiram estímulo e voz, ao mesmo tempo que facultaram aos simpatizantes a possibilidade de reverem considerações e criações próprias em palavra impressa com a sua assinatura. Ao público próximo, procuravam corresponder com envolvência, de modo a tocar, e configurar, os motivos e os gostos diferentes de quem as procurava como alimento espiritual. Em vista estava, por regra, o objectivo de converter um movimento de ideias numa corrente de opinião culta e civicamente interventiva. Pensamento e acção estariam, aliás, muito próximos, de tal modo se conferia à simples afirmação doutrinária mérito histórico e social muito relevante. Os numerosos confrontos polémicos que atravessaram o período considerado e a disposição da vida cultural segundo escolas de pensamento e linhas de sensibilidade bem definidas atestam-no inequivocamente. A divulgação doutrinária e crítica não se circunscrevia ao domínio superlativo das concepções, mas era já acção: acção civilizadora, patriótica, revolucionária, pedagógica, prosélita, épatante ou, simplesmente, heterodoxa, marginal, dialogante. Porém, em qualquer caso, acção: gesto primeiro, condição prévia de todos os outros que na palavra programática recolheriam o sentido. O próprio teor da publicação o expressaria, na dupla vertente de exposição de ideias e das disposições pragmáticas por estas plasmadas, já que a estrutura e o teor da publicação se encontravam tão vinculados à letra enunciada quanto ao cumprimento da missão cultural e colectiva por esta prescrita.

Revistas, intelectuais, ideias emancipadoras e acção imperiosa constituíram, pois, um todo, desdobrado nas sucessivas vagas de sistemas de pensamento e de sínteses da história em que a pretensão ilustrada de captar a natureza e o devir humanos frutificou.

Como facilmente se pode depreender das condições que presidiram à origem dos periódicos de ideias, a elevação e o derrube das doutrinas políticas, sociais ou estéticas obedeceram ao ciclo das gerações, à oposição entre aqueles que tinham menos de trinta anos e os que tinham mais de quarenta, como se pode ler em artigo programático de Sol Nascente ${ }^{27}$. A futuração da vida colectiva, em que o mundo e o

27 Agnelo Mendes e Lúcio Teixeira,"Para elucidação dos de mais de quarenta anos sobre a geração dos de menos de trinta" (Sol Nascente, n. ${ }^{\circ}$ 30, 1.7.1940, p. 5). Este artigo, assinado com pseudónimos irónicos e significativos, vem na sequência de um artigo de Jofre Amaral Nogueira, "O papel duma nova geração” 
tempo encontravam imagem e projecção, apontava mesmo para a convicção de que os novos, pelo simples motivo de o serem, estariam mais perto das fontes de sentido e de ímpeto das coisas humanas.

Ora, uma geração, quando considerada nas suas figuras tutelares, é, como escreveu Eduardo Lourenço, "sempre bem pouca gente" ${ }^{28}$, poucos mais do que os ralos maîtres-à-penser pátrios que ficaram conhecidos como expoentes de cada uma das sucessivas e inovadoras orientações culturais e políticas.

A historiografia da cultura e dos produtos culturais tomou o conceito de geração, decorrente da observação de forte e regular semelhança entre vários homens coetâneos, como apropriado para descrever esta sucessão de vagas de intelectuais, associando-lhe frequentemente as revistas que lhes serviram de órgãos, mais ou menos informais, mesmo quando estas se revelaram tão episódicas quanto fulgurantes, como aconteceu com Orpheu e a sua geração. O mesmo ocorreu nos casos em que autores nascidos num mesmo lustro deram lugar a movimentos culturais cívicos muito distintos entre si, mesmo opostos, como se verificou, nomeadamente, com integralistas e seareiros ${ }^{29}$. A noção de geração - aplicada a conjuntos de novos autores, em oposição polémica às concepções das gerações anteriores, com uma respiração do tempo particular e unidos por uma visão conceptual e programática própria - tornou-se, então, não só um instrumento descritivo sugestivo, como igualmente objecto teórico, discutido na história das letras e das artes, rejeitado por alguns e elevado a questão relevante da epistemologia do saber histórico por outros ${ }^{30}$.

Porém, e independentemente do programa de cada nova vaga de intelectuais, despertar e erguer os portugueses foi desígnio sucessivamente repetido, como se pode depreender das palavras com que Mário Dionísio - volvidos oitenta anos após a carta- circular em que Eça havia anunciado a Revista de Portugal - se referiu retrospectivamente à produção literária dos jovens seus contemporâneos que resultaria do desejo

(Sol Nascente, n. ${ }^{\circ} 28,15.4 .1938$, pp. 6 e 7), e de um inquérito acerca das mesmas questões em curso nas páginas de $O$ Diabo.

${ }^{28}$ Eduardo Lourenço, Sentido e Forma da Poesia Neo-realista, Lisboa, Editora Ulisseia, 1968, p. 38.

29 António Sérgio (1883), Raul Proença (1884), Hipólito Raposo (1885) e António Sardinha (1887) nasceram num lapso de cinco anos.

30 Vide, v. g., Julián Marías, El método histórico de las generaciones, Madrid, Revista de Occidente, 1949, e Benedetto Croce, La storia come pensiero e como azione, Bari, Laterza, 1938. O estudo de Julián Marías vem na sequência da tese de que a história é constituída por gerações, desenvolvida, em diferentes estudos publicados nas décadas de 1930 e 1940, por Ortega y Gasset. 
compartilhado de produzir obras "capazes de acordarem um país inteiro para a sua própria realidade nacional"31.

Na medida em que, ao longo destas oito décadas, a civilização não deixou de chegar da cidade-luz em caixotes transportados no Sud-Express, Eça e Dionísio, como a generalidade dos intelectuais portugueses, filiaram as suas concepções em correntes de pensamento internacionais, por regra com origem ou intermediação francesa.

As manifestações de alguma originalidade conceptual ou doutrinária foram, ao longo deste período, muito escassas e pouco luminosas, o que fez do pensamento sistemático português um campo marcado claramente pela recepção.

Porém, a situação de intermediários por parte dos intelectuais e a afinidade com publicações estrangeiras por parte das revistas em que estes fizeram obra comum não diminuíram nem a aura nem o valor simbólico dos autores e dos seus órgãos, já que ambos representavam e consignavam o progresso civilizacional, a razão vitoriosa, o sangue e a terra, a fidelidade essencial, o rufar do tempo, segundo as diferentes inclinações vigentes na época, ao introduzirem as grandes figuras da cultura e as principais correntes de pensamento internacionais na cultura portuguesa.

O resultado final foi, por regra, idiossincrático e circunstancial, ao combinar a codificação das concepções importadas e inspiradoras - de Michelet e Proudhon a Mounier e Marcuse - com as referências culturais nacionais, segundo o talento e a criatividade, por vezes notórios, de quem representou o escol da sua geração.

Fora do mérito relativo desta condição corrente, ficaram algumas obras literárias - as de Eça de Queirós, Raul Brandão, Fernando Pessoa, Mário de Sá-Carneiro, entre outras mais recentes - que se elevaram à condição do que de melhor os autores da literatura universal do seu tempo escreveram.

\section{Pensar por artigos}

A actividade intensa desenvolvida pelos intelectuais, bem como pela generalidade dos publicistas, nas páginas das revistas, ao longo do período que vimos a considerar, justifica que se atenda à especificidade do artigo como modalidade de expressão da reflexão individual e como meio de produção e de circulação culturais.

$\mathrm{O}$ artigo distingue-se, antes de mais, por unir pensamento e actualidade, ao visar decifrar o sentido de acontecimentos recentes e próximos. O seu domínio apresenta-se como sendo o de esclarecer o que é novo, ou o que surge sob forma renovada,

\footnotetext{
31 Mário Dionísio,"Prefácio”, in Manuel da Fonseca, Obra Poética, 7. a ed., Lisboa, Editorial Caminho, 1884, p. 22.
} 
e assim vencer, através da integração num fio de sentido, a resistência da experiência indeterminada e do dado imediato amórfico.

Embora toda a interpretação se desenvolva segundo quadros analíticos e conceptuais já constituídos e tenha sido corrente pretender submeter o fluir da vida e do pensamento a corpos doutrinários rígidos, que tudo reduziam a algumas certezas invariáveis, a pertinência própria do artigo situa-se na aresta pela qual o presente une o pensado e o inaudito, a retrospectiva e a prospectiva.

$\mathrm{O}$ artigo surge, deste modo, como a consciência do momento. Por seu intermédio, cada circunstância é acompanhada pela indagação acerca do significado que lhe seria próprio, num esforço incessante de esclarecer o fluir e as inflexões dos acontecimentos.

É a proximidade entre a vida e o pensamento que confere ao artigo um interesse peculiar, inerente tanto ao esforço de esclarecimento individual e colectivo do significado das situações, quanto à definição da oportunidade justa para agir.

Neste aspecto, o artigo cristaliza, no plano da argumentação, o sentido de actualidade, sem efemeridade, próprio das melhores revistas, nas quais o pensado e o vivido surgem indelevelmente associados. Muito do encanto da colecção das edições de um título, por parte daqueles que o elegeram como leitura regular, reside no registo fidedigno das certezas e das dúvidas vividas, que encerraram em si as representações segundo as quais as diferentes situações se deram a conhecer, ao mesmo tempo que enriqueciam a formação e moldavam a vida de cada leitor.

Numa época em que se sentia que o presente - inovador, tenso e incerto - reclamava toda a atenção e toda a determinação dos contemporâneos e em que se acreditava, simultaneamente, ser-se chamado a participar em episódios decisivos para o destino das nações e para a própria humanidade, o sentido da actualidade, dos dilemas e dos desafios imediatos que esta colocava tornou-se particularmente agudo.

Quando "o presente é todo o passado e todo o futuro", como Álvaro de Campos vincou na "Ode Triunfal", publicada no número inaugural da revista Orpheu, os tempos não se compadecem com estudos aturados e retiros prolongados, antes requerem a intervenção próxima e contínua. As circunstâncias não reclamam, então, o génio dos tratadistas e a elaboração de sistemas, pois carecem somente de peças esclarecedoras e acessíveis com que os articulistas e os polemistas iluminem as realidades próximas, comprovem a pertinência dos fundamentos das doutrinas que advogam participem activamente na evolução dos acontecimentos.

A sensação de premência interpretativa e de intervenção responsável fez avultar de tal modo o papel desempenhado pelo artigo na vida cultural que se torna fácil verifi- 
car o predomínio, mesmo a quase exclusividade, desta modalidade reflexiva ao longo de períodos extensos da cultura portuguesa contemporânea.

É de registar que este género jornalístico reúne um conjunto de características que Ihe conferem uma grande plasticidade, de que podem beneficiar quer quem o cultiva, quer quem o lê, pois tanto franqueia a sua redacção a qualquer homem letrado, constituindo a porta de ingresso da generalidade dos publicistas, quanto possibilita uma leitura relativamente acessível, desde logo pelo âmbito necessariamente restrito de questões que aborda.

A qualidade de um qualquer artigo pode ser aferida pela pertinência com que combina o horizonte cultural e doutrinário em que se situa com a análise dos elementos próximos cujo significado pretende apreender. Quando se insinua substantivamente no cerne desta relação, o artigo ascende à condição de género reflexivo maior (podendo mesmo representar a literatura mais estimada, aquela que adiciona novos resultados ao estado geral do saber).

Nos artigos de mérito, a abordagem de novos objectos a partir de uma visão estruturada segundo princípios de inteligibilidade estáveis não se apresenta como um processo de pura confirmação, através da redução do novo ao já adquirido, mas como um processo constitutivo de saber inédito e prospectivo, ainda que, por regra, complementar daquele que se dá previamente por adquirido.

A adição da dimensão problemática a horizontes de referência mais ou menos estáveis encontra-se facilitada por alguns dos atributos do próprio formato do género, pois este envolve uma abordagem da realidade parcelar, contingente, sem intuito sistémico, com revisitação, mais ou menos circular, de questões e de temas nodais, no quadro de inquirições de fundo conjectural e em que o recurso à imagem, à metáfora e à analogia é frequente.

Nos seus aspectos mais originais e inerentes à tentativa de captar a especificidade dos objectos singulares sobre os quais reflecte, o artigo, como indagação racional próxima do concreto, da intuição dos seus sinais e do exercício imaginativo das linhas de tensão e de sentidos que o permitem pensar, acabou frequentemente por se aproximar de uma perspectiva ensaística.

Para um lote muito significativo de pensadores, artigo e ensaio tornaram-se então as duas vertentes de um mesmo esforço de esclarecimento simultaneamente crítico, problematizante e cívico. 


\section{Obstáculo e fundamento}

A circunstância de as revistas terem sido, ao longo da centúria considerada, um dos palcos mais significativos da produção e da circulação cultural e de ideias coloca algumas questões peculiares à investigação histórica.

A parte mais visível dos problemas específicos inerentes a estas fontes é relativamente clara: não é fácil encontrar colecções completas dos títulos principais, mesmo nas bibliotecas de referência; alguns dos periódicos reputados conheceram centenas de edições, que ocupam dezenas de milhares de páginas; a recolha dos dispersos de um autor e a reconstituição do seu percurso editorial obrigam à consulta de numerosas edições de muitos títulos diferentes; os textos cuja autoria é difícil de estabelecer, por não se encontrarem assinados ou pelo recurso a pseudónimo, são frequentes; a identificação da orientação editorial de cada título, para além das explicitações programáticas, em manifestos ou editoriais, apresenta-se frequentemente, face à complexidade dos materiais publicados, por vezes ao longo de decénios, problemática e contraditória.

O reconhecimento da importância de que a publicação de revistas de ideias e cultura se revestiu na história recente apresenta-se, pois, proporcional aos obstáculos colocados à investigação por fontes de acesso difícil, muito numerosas, extensas e relativamente uniformes.

Com excepção de alguns estudos parcelares, nomeadamente no âmbito das revistas do campo literário, o conhecimento da história cultural e política portuguesa, tal como se desdobrou nas páginas dos periódicos que lhe deram realidade, tem ficado paralisado pelas dificuldades apontadas.

A superação destes obstáculos epistemológicos pode retirar, actualmente, partido de soluções técnicas de gestão da informação muito favoráveis.

Em termos gerais, um programa adequado à apreensão e interpretação do teor das revistas de ideias e cultura deve ter em consideração a reedição electrónica de lotes de títulos significativos, agrupados, num primeiro momento, segundo as suas afinidades programáticas; a elaboração de bases de dados com os analíticos de todas as peças publicadas, de acordo com as práticas consagradas e adequadas; a possibilidade de consulta das peças constantes nas reedições a partir de índices de autor, de conceitos, de temas, entre outros; o acompanhamento da actividade editorial electrónica com a elaboração de estudos monográficos sobre cada título, incluindo a elaboração de notas acerca dos autores, conceitos, temáticas e recepções mais significativos. 
As condições indispensáveis para o mapeamento de conjuntos cada vez mais amplos de títulos significativos, no plano cultural, ideológico e político, ficariam então asseguradas.

A riqueza, a complexidade, a extensão e a variedade da produção cultural de muitas centenas de autores relevantes, nas páginas dos periódicos de cultura e ideias, deixariam, presumivelmente, de representar um obstáculo ao conhecimento do pensamento e da acção contemporâneos, para se converterem finalmente no seu fundamento. 